\title{
Basic principles of fracture treatment in children
}

\author{
Çocuklarda kırık tedavisinin temel prensipleri
}

\author{
Hakan Ömeroğlu, MD' \\ Department of Orthopedics and Traumatology, TOBB University of Economics and Technology, Faculty of Medicine, Ankara, Turkey
}

\begin{abstract}
This review aims to summarize the basic treatment principles of fractures according to their types and general management principles of special conditions including physeal fractures, multiple fractures, open fractures, and pathologic fractures in children. Definition of the fracture is needed for better understanding the injury mechanism, planning a proper treatment strategy, and estimating the prognosis. As the healing process is less complicated, remodeling capacity is higher and non-union is rare, the fractures in children are commonly treated by non-surgical methods. Surgical treatment is preferred in children with multiple injuries, in open fractures, in some pathologic fractures, in fractures with coexisting vascular injuries, in fractures which have a history of failed initial conservative treatment and in fractures in which the conservative treatment has no/little value such as femur neck fractures, some physeal fractures, displaced extension and flexion type humerus supracondylar fractures, displaced humerus lateral condyle fractures, femur, tibia and forearm shaft fractures in older children and adolescents and unstable pelvis and acetabulum fractures. Most of the fractures in children can successfully be treated by non-surgical methods.

Keywords: Children; classification; fracture; treatment.
\end{abstract}

About one out of every four injuries in children is accompanied by a fracture and about one third of children sustain at least one fracture from birth to 16-17 years of age. ${ }^{[1]}$ The risk of fracture makes its peak just prior to the adolescent period in girls and at the adolescent period in boys. ${ }^{[1-5]}$ Accidental trauma, non-accidental trauma and pathologic conditions are the three main causes of fractures in children. ${ }^{[2]}$ A considerable rise in the incidence of fractures in children has been observed due to changes in life style, increasing rate of childhood obesity, increasing
ÖZ

$\mathrm{Bu}$ derlemede çocuklarda tiplerine göre kırıkların temel tedavi prensipleri ve fizis kırıkları, çoklu kırıklar, açık kırıklar ve patolojik kırıkları içeren özel durumların genel yönetim prensipleri özetlendi. Yaralanma mekanizmasını daha iyi anlamak, uygun bir tedavi stratejisi belirlemek ve prognozu tahmin etmek için kırı̆ı̆ın tanımlanması gereklidir. İyileşme süreci daha az komplike, yeniden şekillenme kapasitesi daha yüksek ve kaynamama seyrek olduğu için çocuklarda kırıklar çoğunlukla cerrahi dışı yöntemlerle tedavi edilir. Çoklu yaralanması olan çocuklarda, açık kırıklarda, bazı patolojik kırıklarda, damar yaralanması eşlik eden kırıklarda, öncesinde başarısız konservatif tedavi öyküsü olan kırıklarda ve femur boyun kırıkları gibi konservatif tedavinin hiç yeri olmadığı/az yeri olduğu kırıklarda, bazı fizis kırıklarında, deplase ekstansiyon ve fleksiyon tipi humerus suprakondiler kırıklarında, deplase humerus lateral kondil kırıklarında, büyük çocuklar ve ergenlerdeki femur, tibia ve önkol cisim kırıklarında, instabil pelvis ve asetabulum kırıklarında cerrahi tedavi tercih edilir. Çocuklarda kırıkların çoğu cerrahi dışı yöntemlerle başarıyla tedavi edilebilir.

Anahtar sözcükler: Çocuklar; sınıflama; kırık; tedavi.

interest in participating in sports activities and increasing the production of motor vehicles, which concomitantly increase the risk of traffic accidents. ${ }^{[4,6]}$

In this review, we aimed to summarize the basic treatment principles of fractures according to their types and general management principles of special conditions including physeal fractures, multiple fractures, open fractures, and pathologic fractures in children. The management of individual fractures in different anatomical sites will not be covered in this review.

- Received: September 26, 2017 Accepted: November 11, 2017

- Correspondence: Hakan Ömeroğlu, MD. TOBB ETÜ Ekonomi ve Teknoloji Üniversitesi Tıp Fakültesi Ortopedi ve Travmatoloji Anabilim Dalı, 06560 Söğütözü, Ankara, Turkey. Tel: +90 312 - 2929900 / 1690 e-mail: omeroglu.h@gmail.com 


\section{Goals of Fracture Treatment in Children}

The goals of fracture treatment in children are; $;^{[7]}$

1. To provide fracture reduction by open or closed means and maintain fracture reduction by casts, splints, braces, traction, internal or external fixation

2. To achieve an anatomic reduction without further injuring the growth plate in physeal fractures

3. To protect the soft tissues

4. To facilitate the fracture healing

5. To allow early mobilization

6. To permit early joint motion

7. To avoid complications including malunion, non-union, premature physeal closure, infection, skin breakdown, joint stiffness, hardware failure, symptomatic hardware, compartment syndrome, and iatrogenic neurovascular injury

As the healing process is less complicated and non-union is rare, the fractures in children have mostly been treated by non-surgical methods for many years. ${ }^{[8]}$ Lower modulus of bone elasticity can lead to some specific pediatric age group fractures such as traumatic bowing, torus fracture and greenstick fracture which can commonly be treated by conservative means. Remodeling capacity that is better in younger children, in fractures close to growth plates and in fractures having an angulation in the motion plane of the nearest joint is perhaps the most significant factor, leading to the preference of non-surgical treatment in most of the fractures in children. ${ }^{[1,9-12]}$

There is a current trend toward surgical treatment due to improved medical technology, public health education, changes in life style, minimal hospitalization requirements and parents' expectations on obtaining perfect outcomes. ${ }^{[6]}$ The current trend toward surgical treatment is more evident in upper extremity fractures, although closed reduction and casting is still a widely preferable method. ${ }^{[13]}$ Age, body-mass index, site, type and severity of the fracture, coexisting injuries, socioeconomic factors as well as other patient/ surgeon/hospital related factors influence the choice of fracture treatment method. Surgical treatment is preferred in children with multiple injuries, in open fractures, in some pathologic fractures, in fractures with coexisting vascular injuries, in fractures which have a history of failed initial conservative treatment, in fractures in which the conservative treatment has no/little value such as femur neck fractures, some physeal fractures, displaced extension and flexion type humerus supracondylar fractures, displaced humerus lateral condyle fractures, femur, tibia and forearm shaft fractures in older children and adolescents and unstable pelvis and acetabulum fractures. ${ }^{[6,7,11,14,15]}$

\section{Basic Treatment Principles According to the Type of the Fracture}

The classification of fractures has been used in almost all bone injuries both in adults and children for many years. A classification is needed for better understanding the injury mechanism, planning a proper treatment strategy, and estimating the prognosis.
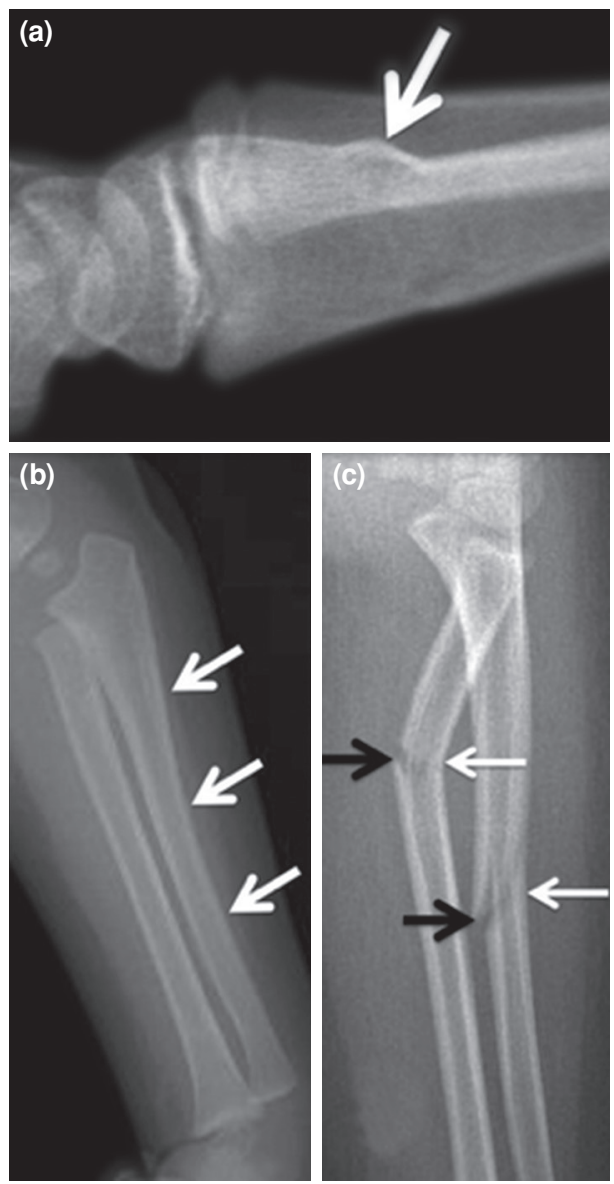

Figure 1. Types of incomplete fractures in children. (a) Torus fracture of distal radius (arrow). (b) Traumatic bowing of ulna. Note that posterior convex bowing of ulna in lateral radiograph is lost and becomes concave (arrows). (c) Greenstick fracture of forearm (black arrows indicate failure sides and white arrows indicate plastic deformation sides). 


\section{Definition and Treatment Principles of Incomplete Fractures}

Torus (buckle) fracture: It is defined as the failure and bulging of the thin cortex at the metaphysisdiaphysis junction of a long bone due to a longitudinal force applied along the axis of the affected limb. Such a fracture is commonly seen in the distal radius (Figure 1a). ${ }^{[1,11]}$ Fracture healing is rapid and an immobilization period of three-four weeks is commonly sufficient to relieve pain. Non-rigid immobilization methods (soft cast, splint, bandage, slab) have been reported to be more advantageous than rigid immobilization by cast in forearm torus fractures. ${ }^{[16]}$

Traumatic bowing: It is defined as the plastic deformation of the bone due to trauma. The applied force to a long bone is greater than the elasticity of the bone but is not sufficient to produce an apparent fracture. It is mostly seen in ulna and fibula (Figure 1b). ${ }^{[1,10,11]}$ Traumatic bowing of the ulna is commonly accompanied by radial head dislocation (Monteggia lesion) and it is mandatory to assess the proximal radioulnar joint in such cases. A reduction maneuver is recommended in an isolated traumatic bowing of the forearm, when the angulation is more than 20 degrees or if the child is older than four years and there is an evident clinical deformity. ${ }^{[10]}$

Greenstick fracture: If the applied force to a long bone exceeds the limit of plastic deformation but is still insufficient to generate a complete failure of the entire bone structure, then it is called a greenstick fracture. There exists a failure on the tension (convex) side and plastic deformation on the compression (concave) side (Figure 1c). ${ }^{[1,10,11]}$ It is essential to achieve an acceptable reduction in such a fracture. However, completing the fracture on the compression side to reduce the fracture is still controversial. ${ }^{[10]}$

Stress fracture: Stress fracture is an overuse injury due to repetitive stress. It is commonly seen in children who are involved in sports activities and running sports, which are the most common cause of such a fracture. ${ }^{[11,17]}$ Proximal tibia, fibula, metatarsal bones, pelvis, femur neck and diaphysis are the most common sites. In case of a stress fracture, it is needed to eliminate the sports activity for a certain time period. Immobilization is usually recommended to overcome pain and to avoid the fracture to be complete. ${ }^{[11,17]}$ Femur neck stress fractures are usually treated by surgical means. ${ }^{[17]}$
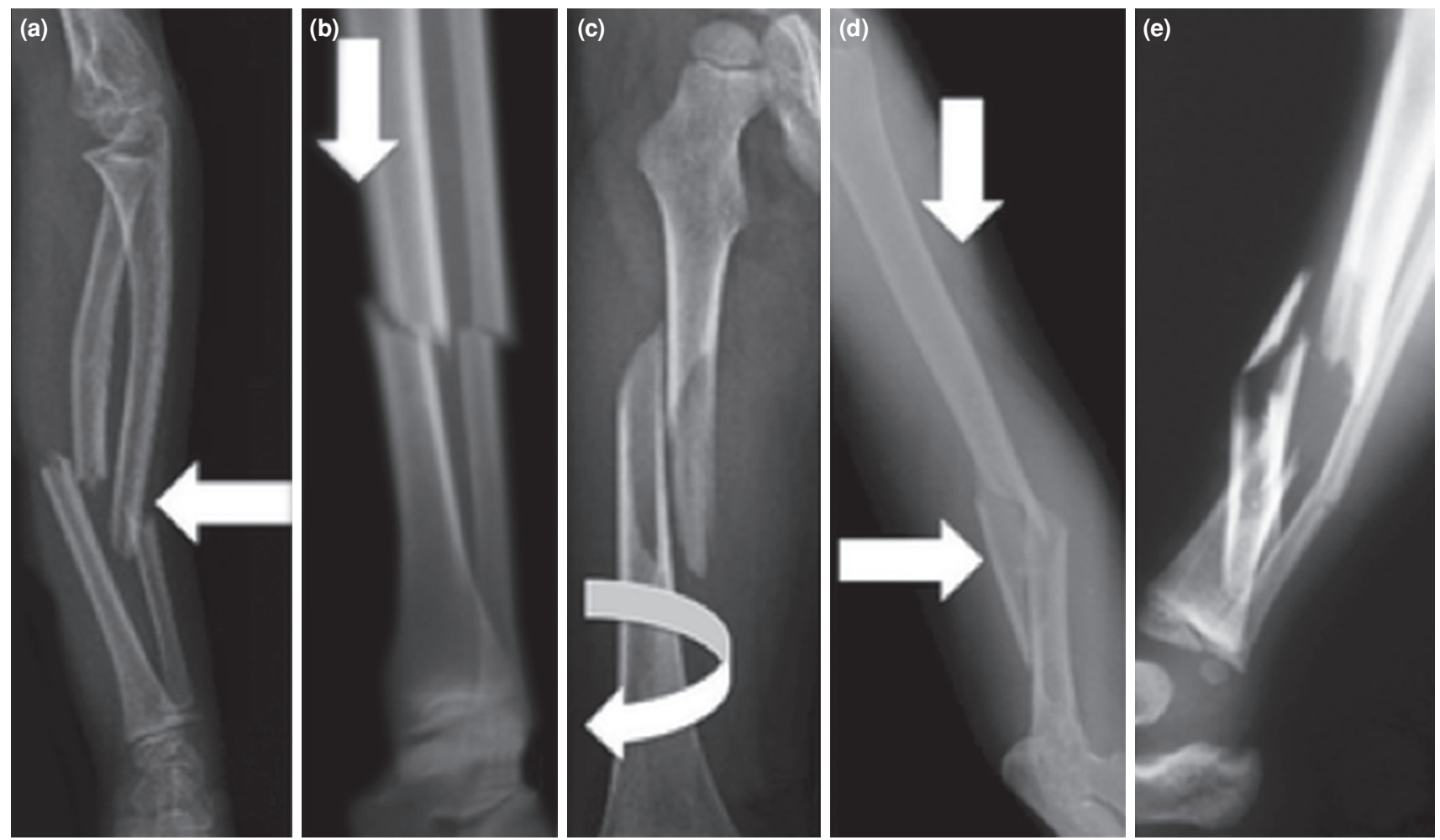

Figure 2. Classification of complete fractures according to fracture pattern. Arrows show direction of applied forces to produce fractures. (a) Transverse fractures of radius and ulna shafts. (b) Oblique fracture of tibia shaft. (c) Spiral fracture of femur shaft. (d) Butterfly fracture of distal third of humerus shaft. (e) Comminuted fracture of tibia shaft. 

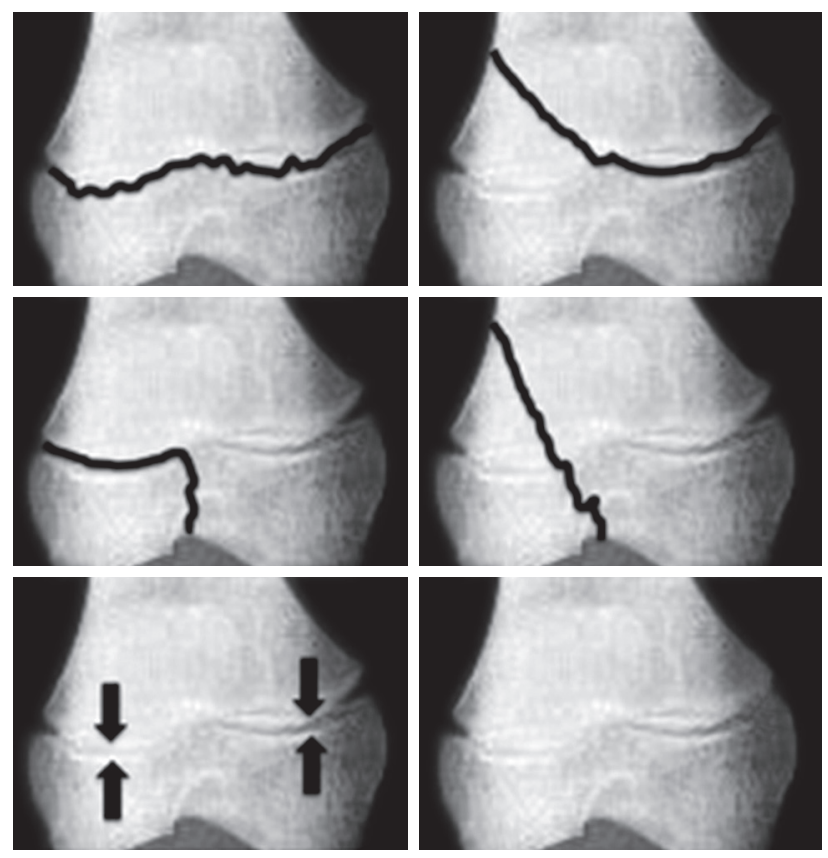

Figure 3. Salter-Harris physeal fracture classification system.

\section{Definition and Treatment Principles of Complete Fractures}

Complete fractures can involve diaphysis, metaphysis and are similar to adult fractures. Besides, such fractures can involve the epiphysis and growth plate. The fracture pattern is directly related with the direction of the applied force to the long bone. The fracture pattern may be helpful for determining the most effective reduction maneuver and the way of cast molding.

Transverse fracture: The applied force to the long bone at the fracture site is perpendicular to the long axis of the bone. This force produces angulation and the periosteum is torn on the opposite side (tension side). Meanwhile, some part of the periosteum on the compression (concave) side is usually left intact (Figure 2a). Transverse fracture is best reduced by increasing the deformity up to $90^{\circ}$ and then straightening and pulling the distal fragment. Threepoint molding of the cast is required to maintain the reduction in cast in such a fracture. ${ }^{[1,11]}$

Oblique fracture: Oblique fracture is produced by the compression force (axial loading). The periosteum is widely torn. Oblique fracture is considered to be unstable (Figure 2b). Oblique fracture is best reduced by straight pull. It may sometimes be difficult to maintain the reduction in the cast that should be applied with circumferential pressure around the fracture site. ${ }^{[1,1]}$
Spiral fracture: Spiral fracture is caused by torsional force. A longitudinal band of periosteum is left intact. This longitudinal periosteal hinge provides sufficient longitudinal stability following reduction (Figure 2c). Spiral fracture is best reduced by rotation of the distal fragment back to its original position. It is better to apply a crank-handle cast (right angles at adjacent joints) for controlling the rotation in such a fracture. ${ }^{[1,11]}$

Butterfly fracture: A combination of compression (axial loading) and perpendicular (angulation) forces produce this fracture. The butterfly fragment is located on the side where the bone has been hit. There is significant periosteum damage, but it is more evident on the opposite side of the butterfly fragment. This fracture is obviously unstable (Figure 2d). Distraction is required for reduction in butterfly fractures and three-point pressure may be useful for maintenance of the reduction in the cast. However, the risk of failure following such a treatment should always be kept in mind in butterfly fracture. ${ }^{[1,11]}$

Comminuted fracture: It is due to high-energy trauma. However, comminuted fracture rarely occurs in childhood due to previously described biological characteristics of the child's bone (Figure 2e). ${ }^{[1,11]}$

\section{Treatment Principles of Special Conditions}

\section{Growth Plate Injuries (Physeal Fractures)}

About one out of every five fractures in children involves the growth plate. ${ }^{[2]}$ Such an injury can cause growth disturbance and this is mainly due to damage to the germinal cells, loss of vascular supply or crushing/infection of the growth plate, formation of a bone bridge between epiphysis and metaphysis. ${ }^{[1,9,11]}$ Most of the fractures occur through the hypertrophic zone of the growth plate (zone of provisional calcification). The rate of permanent growth plate damage, which results in significant growth disturbance, ranges from $1 \%$ to $10 \%$ in physeal fractures. ${ }^{[1]}$

According to the Salter-Harris classification, ${ }^{[18]}$ which is most commonly used to classify growth plate injuries (Figure 3), a secure closed reduction is possible and significant short or long term problems are rare in most of the type I injuries except in type I displaced proximal femur fractures. ${ }^{[1,10,11]}$ Long-term sequel is rare and secure closed reduction can be achieved in most of the type II injuries, the mostly common seen type. Open reduction and internal fixation may be required in some locations such as distal femur where the risk of growth disturbance exists in such injuries. ${ }^{[1,10,11]}$ Type III and 
type IV injuries are intraarticular fractures. Growth disturbance, joint stiffness and non-union can be seen and open reduction and internal fixation are frequently preferred to restore both the joint and growth plate anatomy and to avoid joint stiffness, non-union and growth disturbance. ${ }^{[1,10,1]}$

\section{Open Fractures}

The rate of open fractures in children is about 3\% and the most affected site is tibia like in adults. ${ }^{[1,2,19]}$ The rate of severe open fractures in children is half the rate of that in adults. Although it has been stated that the treatment of open fractures in children is similar to that in adults, the level of scientific evidence concerning this statement is low. Irrigation and debridement of the wound, reduction and stabilization of the fracture, infection prophylaxis by antibiotics and early soft tissue coverage are the essential steps of the treatment. ${ }^{[1,19]}$ Age ( $>10$ years) and severity of the open fracture (grade III) are the main determinants of higher complication rate and poorer prognosis in pediatric open tibia fractures. ${ }^{[19]}$

\section{Multiple Fractures}

The rate of multiple fractures in children is approximately $4 \%{ }^{[2]}$ The timing of fracture fixation in a multiply injured child still remains controversial. However, recent evidence has shown that early fracture fixation provides several non-orthopaedic benefits to a child with multiple injuries. The care plan should be individualized and it is essential to perform the definitive fracture fixation following the management of life-threatening conditions and as soon as the patient's medical condition permits. ${ }^{[1,7,9]}$

\section{Pathologic Fractures}

A pathologic fracture is defined as a fracture that occurs through abnormal bone and identification of such a fracture may be challenging. Pathologic fractures can occur due to local bone diseases (tumors, tumor-like processes, osteomyelitis), bone marrow diseases (Gaucher's disease, sickle-cell disease, leukemia, hemophilia) or systemic disorders, which cause general bone weakness (osteogenesis imperfecta, osteopetrosis, rickets, hyperparathyroidism, neuromuscular disorders). Treatment type varies in different conditions. ${ }^{[1,11,20]}$

Unicameral bone cyst (UBC) is considered to be the most common cause of pathologic fractures in children. Proximal humerus and proximal femur are the two most common sites for the pathologic fracture due to UBC. ${ }^{[21]}$ The primary aim is to precisely treat the cyst and to prevent future fractures and deformity. If a stable and minimally displaced fracture occurs in a non-weight bearing area, then a simple immobilization is applied first. If the cyst persists after fracture treatment, then the definitive treatment of the cyst is performed. If the fracture is unstable or occurs in a weight-bearing area, it may be better to perform bone fixation and cyst treatment, concomitantly. ${ }^{[21]}$

\section{Declaration of conflicting interests}

The authors declared no conflicts of interest with respect to the authorship and/or publication of this article.

\section{Funding}

The authors received no financial support for the research and/or authorship of this article.

\section{REFERENCES}

1. Herman MJ, McCarthy JJ. The principles of pediatric fracture and trauma care. In: Weinstein SL, Flynn JM. editors. Lovell and Winter's Pediatric Orthopaedics. 7th ed. Philadelphia: Wolters Kluwer; 2014. p. 1661-93.

2. Brighton B, Vitale M. Epidemiology of fractures in children. In: Flynn JM, Skaggs DL, Waters PM, editors. Rockwood and Wilkins' Fractures in Children. 8th ed. Philadelphia: Wolters Kluwer; 2015. p. 1-17.

3. Cooper C, Dennison EM, Leufkens HG, Bishop N, van Staa TP. Epidemiology of childhood fractures in Britain: a study using the general practice research database. J Bone Miner Res 2004;19:1976-81.

4. Hedström EM, Svensson O, Bergström U, Michno P. Epidemiology of fractures in children and adolescents. Acta Orthop 2010;81:148-53.

5. Landin LA. Fracture patterns in children. Analysis of 8,682 fractures with special reference to incidence, etiology and secular changes in a Swedish urban population 1950-1979. Acta Orthop Scand Suppl 1983;202:1-109.

6. Kosuge D, Barry M. Changing trends in the management of children's fractures. Bone Joint J 2015;97:442-8.

7. Musgrave DS, Mendelson SA. Pediatric orthopedic trauma: principles in management. Crit Care Med 2002;30:431-43.

8. Atik OŞ. Do we surgeons perform surgery only? Eklem Hastalik Cerrahisi 2016;27:123-4.

9. Gladden PB, Wilson CH, Suk M. Pediatric orthopedic trauma: principles of management. Semin Pediatr Surg 2004;13:119-25.

10. Herring JA. Tachdjian's Pediatric Orthopedics. 5th ed. Philadelphia: Elsevier Saunders; 2014.

11. Wenger DR, Pring ME. Rang's children's fractures. 3rd ed. Philadelphia: Lippincott Williams \& Wilkins; 2005.

12. Wilkins KE. Principles of fracture remodeling in children. Injury 2005;36:3-11.

13. Helenius I, Lamberg TS, Kääriäinen S, Impinen A, Pakarinen MP. Operative treatment of fractures in children is increasing. A population-based study from Finland. J Bone Joint Surg [Am] 2009;91:2612-6.

14. Aksakal M, Ermutlu C, Sarısözen B, Akesen B. Approach to supracondylar humerus fractures with neurovascular compromise in children. Acta Orthop Traumatol Turc 2013;47:244-9. 
15. Turgut A, Kalenderer Ö, Bozoğlan M, Bacaksız T, Ağuş $\mathrm{H}$. Flexion type supracondylar humerus fractures: 12 year experience of a pediatric orthopedics clinic. Eklem Hastalik Cerrahisi 2015;26:151-7.

16. Jiang N, Cao ZH, Ma YF, Lin Z, Yu B. Management of Pediatric Forearm Torus Fractures: A Systematic Review and Meta-Analysis. Pediatr Emerg Care 2016;32:773-778.

17. Willis RB, Kocher MS, Ganley TJ. Sports medicine in the growing child. In: Weinstein SL, Flynn JM, editors. Lovell and Winter's Pediatric Orthopaedics. 7th ed. Philadelphia: Wolters Kluwer; 2014. p. 1596-660.

18. Salter RB, Harris WR. Injuries involving the epiphyseal plate. J Bone Joint Surg [Am] 1963;45:587-622.

19. Gougoulias N, Khanna A, Maffulli N. Open tibial fractures in the paediatric population: a systematic review of the literature. Br Med Bull 2009;91:75-85.

20. Arkader A, Dormans J. Pathologic fractures associated with tumors and unique conditions of the musculoskeletal system. In: Beaty JH, Kasser JR, editors. Rockwood and Wilkins' Fractures in Children. 7th ed. Philadelphia: Lippincott Williams \& Wilkins; 2010. p. 120-91.

21. De Mattos CB, Binitie O, Dormans JP. Pathological fractures in children. Bone Joint Res 2012;1:272-80. 